\title{
FAKTOR YANG MEMENGARUHI KEJADIAN DERMATITIS KONTAK PADA PETUGAS PENGANGKUT SAMPAH DI TEMPAT PEMBUANGAN AKHIR (TPA) SAMPAH-KOTA TEMBILAHAN TAHUN 2019
}

\author{
Salmariantity ${ }^{1}$, Mitra $^{2}$, M. Kamali Zaman ${ }^{3}$ \\ ${ }^{1,2,3}$ Program Studi Magister Kesehatan Masyarakat, \\ ${ }^{1,3}$ STIKes Hang Tuah Pekanbaru \\ Email: salmariantity2@gmail.com
}

Diterima: Juni 2021, Diterbitkan: Juni 2021

\begin{abstract}
ABSTRAK
Sampah selain dapat mengganggu estetika atau keindahan, sampah juga dapat menyebabkan terjadinya banjir dan gangguan kesehatan atau penyakit bagi manusia. Penyakit kulit merupakan salah satu penyakit akibat kerja yang sangat sering ditemukan. Berdasarkan hasil Riskesdas, 2007, dermatitis di Riau menyumbang sekitar 47,6 \% (persen) berasal dari pekerja penglola sampah dan di Indragiri Hilir menyumbang kasus dermatitis sebesar 6,3\%. Penelitian ini bertujuan untuk mengetahui Faktor Yang Mempengaruhi Kejadian Dermatitis Kontak Pada Petugas Pengangkut Sampah di TPA Sampah Kota Tembilahan. Jenis penelitian dalam penelitian ini adalah analitik dengan desain crossectional. Populasi dalam penelitian ini adalah seluruh petugas pengangkut sampah di Kota Tembilhan Tahun 2018 sebanyak 294 orang. Analisa data dilakukan secara univariat, bivariat dan multivariate menggunakan uji regeresi logistik berganda. Hasil penelitian menemukan petugas pengangkut sampah dengan personal higiene tidak baik berpeluang untuk mengalami dermatitis kontak 4.94 kali, lama kontak $>8$ jam berpeluang untuk mengalami dermatitis kontak 3.86 kali, umur $<31$ tahun berpeluang untuk mengalami dermatitis kontak 41.78 kali lebih tinggi dibandingkan dengan umur $\geq 31$ tahun, jenis kelamin perempuan berpeluang untuk mengalami dermatitis kontak 2.78 kali dan ada hubungan antara penggunaan APD dengan kejadian dermatitis kontak (pvalue $=0.00$ ). Disarankan dari hasil penelitian ini kepada petugas sampah untuk selalu menjaga personal hygiene, kapan kontak dengan sampah, dan usia yang tepat dalam mengangkut sampah agar tidak terjangkit Dermatitis Kontak.
\end{abstract}

Kata Kunci : Dermatitis Kontak, Faktor Risiko

\begin{abstract}
Waste can not only disturb aesthetics or beauty, it can also cause flooding and health problems or diseases for humans. Skin disease is an occupational disease that is very often found. Based on the results of Riskesdas, 2007, dermatitis in Riau accounted for around 47.6\% (percent) coming from waste management workers and in Indragiri Hilir accounted for $6.3 \%$ of dermatitis cases. This study aims to determine the Factors Affecting the Occurrence of Contact Dermatitis in Garbage Transport Officers at Tembilahan City Landfill. The type of research in this study is analytic with cross-sectional design. The population in this study were all garbage transport officers in Tembilhan City in 2018 as many as 294 people. Data analysis was performed univariate, bivariate and multivariate using multiple logistic regression tests. The results of the study found that garbage transporters with bad personal hygiene have a 4 chance of having contact dermatitis, contact time $>8$ hours have a chance to experience contact dermatitis 3.86 times, age <31 years have a chance to experience contact dermatitis 41.78 times higher than age $\geq 31$ years, female gender has the opportunity to experience contact dermatitis 2.78 times and there is a relationship between the use of PPE with the incidence of contact dermatitis (pvalue $=0.00$ ). It is recommended from the results of this study to the garbage officer to always maintain personal hygiene, when to contact with garbage, and the right age in transporting waste so as not to contract contact dermatitis.
\end{abstract}

Keywords : Contact Dermatitis, Risk Factors 


\section{PENDAHULUAN}

Sampah selain dapat mengganggu estetika atau keindahan, sampah juga dapat menyebabkan terjadinya banjir dan gangguan kesehatan atau penyakit bagi manusia. Sampah dapat menjadi tempat tinggal seperti serangga, tikus, cacing, jamur, virus, bakteri, parasit yang dapat menimbulkan penyakit (Mukono, 2011).

Penyakit akibat sampah sangat luas dan dapat berupa penyakit menular, tidak menular dapat juga berupa kebakaran, keracunan, dan lain-lain. Selain itu sampah juga dapat menyebabkan meningkatnya penyakit-penyakit yang ditularkan melalui vektor berupa bakteri, jamur, virus, parasit, cacing dan zat kimia. Salah satu penyakit akibat sampah adalah penyakit kulit yang disebabkan beberapa jenis jamur mikroorganisme patogen yang hidup dan berkembang biak di dalam sampah (Soemirat, 2009).

Hasil penelitian dari Nicholson (2002) tentang occupational health in the european union menyatakan harus ada kerja sama pemerintah dengan stakeholder, dengan membuat sistem manajemen yang dilaksanakan guna memperkecil bahaya dari pekerjaan. Kemudian hasil training oleh ethiopia public health (2002) menjelaskan alat pelindung diri merupakan salah satu tindakan pengendalian bahaya di tempat kerja. Sedangkan Richard dalam occupational contact dermatitis pemakaian alat pelindung diri (APD) merupakan hal yang penting untuk tenaga kerja untuk menghindari kontak langsung. Kemudian Ibler (2012) dalam Richard menyatakan bahwa pemilihan alat pelindung diri (APD) yang sesuai dengan pekerjaan merupakan salah satu cara untuk menghindari terjadi kontak langsung dengan tubuh. Seperti pemilihan sarung tangan yang sesuai dengan pekerjaan untuk melindungi tangan dari bahan organik atau zat kimia.

Hasil penelitian Faridawati (2013) tentang hubungan personal hygiene tentang keluhan gangguan kulit pada pemulung Bantar Gerbang di Jawa Barat menyatakan bahwa ada hubungan yang signifikan antara masa kerja dan kebersihan kulit dengan keluhan gangguan kulit pada pemulung. Kemudian hasil penelitian dari Mahyuni(2012) tentang kelainan kulit (dermatosis) pada pemulung di tempat pembuangan akhir (TPA) terjun Medan Marelan menyatakan bahwa dari 82 sampel terdapat 46 yang mengalami dermatosis akibat kurang baiknya personal hygiene dan tidak adanya pemakaian alat pelindung diri (APD) pada saat bekerja.

Berdasarkan Riset Kesehatan Dasar (Riskesdas, 2007) dermatitis di Riau menyumbang sekitar $47,6 \%$. Sedangkan untuk di daerah Indragiri Hilir menyumbang kasus dermatitis sebesar 6,3\% (Riskesdas, 2007). Berdasarkan data di Puskesmas Gajah Mada Tembilahan tahun 2018 penyakit kulit termasuk ke dalam 10 penyakit terbesar dan rata-rata perbulan selama enam bulan terakhir terdapat 88 pasien yang didiagnosa menderita penyakit kulit.

Petugas pengangkut sampah termasuk pekerja yang belum mendapatkan pelayanan kesehatan sebagaimana mestinya. Petugas pengangkut sampah merupakan sekelompok pekerja yang memiliki risiko tinggi terjangkit penyakit akibat kerja mengingat jenis pekerjaan mereka. Kondisi lingkungan kerja yang berada di lingkungan terbuka sehingga kondisinya berhubungan langsung dengan sengatan matahari, debu dan bau dari sampah. Kondisi tersebut dapat menimbulkan risiko gangguan kesehatan seperti penyakit akibat kerja, kecelakaan kerja dan gangguan ergonomi (Mustikawati, 2015).

Dinas Lingkungan Hidup dan Kebersihan Kab. Indragiri Hilir mempunyai tugas pokok diantaranya penyelenggaraan pelayanan kebersihan, pengangkutan sampah, pemeliharaan kendaraan operasional sampah dan tempat pembuangan sementara (TPS), serta penarikan retribusi. Bidang pengangkut sampah mempunyai standard operating dan procedure (SOP) yang menjadi standar bagi pekerja dalam melaksanakan aktivitas 
sehari-hari. Saat melakukan aktivitas di tempat kerja, tenaga kerja atau petugas pengangkut sampah harus memperhatikan kesehatan dan kebersihan kulit. Seperti penjelasan suma'mur (2009) bahwa kesehatan kerja atau occuptional health bertujuan agar pekerja memperoleh derajat kesehatan dengan usaha preventif salah satunya pemakaian alat pelindung diri (APD) dan kuratif.

Berdasarkan wawancara dengan kepala seksi Dinas Lingkungan Hidup dan Kehutanan (DLHK) Tembilahan mengatakan bahwa setiap tahunnya selalu ada anggaran Alat Pelindung Diri (APD) untuk pengangkut sampah. Anggaran Alat Pelindung Diri (APD) tersebut berupa topi kerja, sarung tangan, sepatu boot, kaos lapangan dan jas hujan. Alat Pelindung Diri (APD) tersebut dianggarkan satu tahun sekali, selain itu ada juga Alat Pelindung Diri (APD) yang diadakan setiap bulannya yaitu sarung tangan. Namun masker yang termasuk kebutuhan Alat Pelindung Diri (APD) yang juga penting tidak dianggarkan dari Dinas Lingkungan Hidup dan Kehutanan (DLHK) Tembilahan.

Selanjutnya wawancara pada petugas pengangkut sampah di Kota Tembilahan, diketahui bahwa terdapat sekitar 20 petugas pengangkut sampah yang mengalami keluhan gatal pada tangan, panas, dan terdapat bercak warna merah yang mulai mengering. Hasil wawancara juga menunjukkan jika personal hygiene seperti tidak langsung mandi setelah selesai bekerja dengan alasan masih ada pekerjaan berikutnya, sehingga mandi setelah semua pekerjaan selesai, memiliki kuku panjang dan hitam, ada juga petugas memakai pakaian yang sudah dipakai bekerja tanpa dicuci kembali dan rata-rata petugas tidak memakai alat pelindung diri seperti sarung tangan, sepatu dan topi yang sesuai standar.

Pekerja pengangkut sampah di TPA Sungai Beringin Kota Tembilahan ada yang bekerja melebihi dari 8 jam karena menggantikan teman atau keluarga yang bekerja di tempat yang sama, dan ada beberapa pekerja pengangkut sampah yang juga bermukim tidak jauh dari TPA tersebut.

Hasil observasi dan wawancara langsung pada beberapa petugas pengangkut sampah tersebut, ditemukan beberapa petugas pengangkut sampah yang mengalami dermatitis, maka perlu dilakukan penelitian untuk menganalisis apakah ada faktor yang mempengaruhi kejadian dermatitis kontak pada petugas pengangkut sampah di Tempat Pembuangan Akhir (TPA) Sampah Kota Tembilahan tahun 2019.

\section{METODE}

Penelitian ini bersifat kuantitatif analitik observasional dengan desain cross sectional. Desain penelitian cross sectional merupakan suatu penelitian yang mempelajari hubungan antara faktor risiko (independen) dengan faktor efek (dependen), dimana melakukan observasi atau pengukuran variabel sekali dan sekaligus pada waktu yang sama. Penelitian ini bertujuan untuk mengetahui Faktor yang mempengaruhi kejadian Dermatitis Kontak pada Petugas Pengangkut Sampah di Tempat Pembuangan Akhir (TPA) Kota Tembilahan Tahun 2019.

Populasi merupakan seluruh subjek yang akan diteliti dan memenuhi karakteristik yang ditentukan. Populasi dalam penelitian ini adalah petugas Pengangkut Sampah di Tempat Pembuangan Akhir (TPA) di Kota Tembilahan. Sampel adalah bagian dari populusi yang diharapkan dapat mewakili atau representatif populasi. Adapun yang dijadikan sampel dalam penelitian ini adalah keseluruhan populasi yaitu 294 responden.

Sampel dalam penelitian ini diambil dengan cara total sampling yaitu menjadikan populasi sebagai sampel penelitian dengan jumlah 294 orang. Adapun kriteria sampel meliputi: Kriteria inklusi yaitu Seluruh petugas Pengangkut Sampah di Tempat Pembuangan Akhir (TPA) Kota Tembilahan. 


\section{HASIL DAN PEMBAHASAN}

\section{Analisa Univariat}

Hasil analisis univariat dari variabel independen yang akan dicari hubungannya dengan kejadian Dermatitis Kontak Pada Petugas Pengangkut Sampah di Tempat Pembuangan Akhir (TPA) Sampah di Kota Tembilahan Tahun 2019 adalah sebagai berikut:

1. Personal higiene tidak baik sebanyak $45.2 \%$

2. Tidak pernah menggunakan APD sebanyak $35 \%$

3. Lama kontak berisiko sebanyak $32.3 \%$

4. Umur berisiko sebanyak $62.9 \%$

5. Jenis kelamin perempuan sebanyak $55.1 \%$

6. Pengetahuan buru sebanyak $78.9 \%$

Tabel 1.

Distribusi Variabel Independen Pada Penelitian Kuantitatif Analitik Tentang Kejadian Dermatitis Kontak Pada Petugas Pengangkut Sampah Di Tempat Pembuangan Akhir (TPA) Kota Tembilahan Tahun 2019

\begin{tabular}{lcc}
\hline \multirow{2}{*}{ Variabel Independen } & \multicolumn{2}{c}{ Jumlah } \\
\cline { 2 - 3 } & n294 & Persen \\
\hline Personal Higiene & & \\
Tidak baik & 133 & 45.2 \\
Cukup & 161 & 54.8 \\
Penggunaan APD & & \\
Tidak Pernah & 103 & 35.0 \\
Jarang & 76 & 25.9 \\
Selalu & 115 & 39.1 \\
Lama Kontak & & \\
Risiko & 95 & 32.3 \\
Tidak risiko & 199 & 67.7 \\
Umur & & \\
$>31$ tahun & 185 & 62.9 \\
$\leq 31$ tahun & 109 & 37.1 \\
Jenis Kelamin & & \\
Perempuan & 162 & 55.1 \\
Laki-laki & 132 & 44.9 \\
Pengetahuan & & \\
Buruk & 232 & 78.9 \\
Baik & 62 & 21.1 \\
\hline
\end{tabular}

\section{Analisa Bivariat}

Tabel 4.2 menunjukkan dari 6 variabel independen semua variabel berhubungan signifikan $(\mathrm{p}<0.05)$ dengan kejadian dermatitis kontak yang dapat dijelaskan sebagai berikut:

a. Petugas pengangkut sampah dengan personal higiene tidak baik berpeluang untuk mengalami dermatitis kontak 4.94 kali lebih tinggi dibandingkan dengan personal higiene cukup (CI 95\% : 2.968.26).

b. Ada hubungan antara penggunaan APD dengan kejadian dermatitis kontak ( $p$ value $=0.00$ )

c. Petugas pengangkut sampah dengan lama kontak $>8$ jam berpeluang untuk mengalami dermatitis kontak 3.86 kali lebih tinggi dibandingkan dengan lama kontak $\leq 8$ jam (CI 95\%: 2.21-6.75).

d. Petugas pengangkut sampah dengan umur < 31 tahun berpeluang untuk mengalami dermatitis kontak 41.78 kali lebih tinggi dibandingkan dengan umur $\geq 31$ tahun (CI 95\%: 1.10-2.87).

e. Petugas pengangkut sampah perempuan berpeluang untuk mengalami dermatitis kontak 2.78 kali lebih tinggi dibandingkan dengan laki-laki (CI 95 persen:1.72-4.78).

f. Petugas pengangkut sampah dengan pengetahuan buruk berpeluang untuk mengalami dermatitis kontak $1.88 \mathrm{kali}$ lebih tinggi dibandingkan dengan pengetahuan baik (CI 95 persen:1.073.31).

\section{Analisa Multivariat}

\section{a. Seleksi Bivariat}

Analisa multivariat ini dilakukan untuk mengukur hubungan antara variabel independen dan variabel dependen dengan menggunakan uji regresi logistik berganda dengan tujuan untuk mengetahui variabel independen mana yang paling besar pengaruhnya terhadap outcome. Dari hasil analisis bivariat digunakan untuk seleksi masuk multivariat, dimana variabel yang $\mathrm{p}<$ 0.25 menjadi kandidat model multivariat Hastono, (2007). Hasil seleksi didapatkan dari analisis bivariat dapat dilihat pada tabel dibawah ini : 
Tabel 3.

Hasil Seleksi Bivariat Untuk Kandidat Multivariat $(P<0.25)$

\begin{tabular}{|c|c|c|c|}
\hline \multicolumn{4}{|c|}{ Multivaria } \\
\hline No & Variabel & $\begin{array}{c}\mathbf{P} \\
\text { value }\end{array}$ & Keterangan \\
\hline 1. & Personal higiene & 0.00 & Kandidat \\
\hline 2. & Penggunaan APD & 0.00 & Kan \\
\hline 3. & Lama Kontak & 0.00 & Kandidat \\
\hline 4. & Umur & 0.025 & Kandidat \\
\hline 5. & Jenis kelamin & 0.00 & Kandidat \\
\hline 6. & Pengetahuan & 0.039 & Kandidat \\
\hline & *menjadi & & berdasark \\
\hline
\end{tabular}

\section{b. Pemodelan Multivariat}

Uji Logistik berganda yang dipakai adalah model prediksi bertujuan untuk memperoleh model yang terdiri dari beberapa variabel independen untuk memprediksi kejadian variabel dependen (Hastono, 2007). Hasil model awal (pemodelan I) seperti pada tabel dibawah ini :

Tabel 4.

Analisis Multivariat (Pemodelan I) Tentang Kejadian Dermatitis Kontak Pada Petugas Pengangkut Di Tempat Pembuangan Akhir (TPA) Sampah Kota Tembilahan Tahun 2019

\begin{tabular}{lccc}
\hline Variabel & $\begin{array}{c}\text { P } \\
\text { valu } \\
\mathbf{e}\end{array}$ & POR & B \\
\hline Personal & 0.00 & 5.99 & 1.79 \\
higiene & 0 & 8 & 1 \\
Penggunaa & 0.02 & 1.47 & 0.38 \\
n APD & 1 & 6 & 9 \\
Lama & 0.00 & 3.16 & 1.15 \\
Kontak & 0 & 7 & 3 \\
Umur & 0.00 & 3.37 & 1.21 \\
& 0 & 7 & 7 \\
Jenis & 0.00 & 2.71 & 1.00 \\
kelamin & 0 & 9 & 0 \\
Pengetahua & 0.14 & 1.63 & 0.49 \\
n & 1 & 4 & 1 \\
Constanta & 0.00 & 0.00 & - \\
& 0 & 0 & 9.68 \\
& & & 0 \\
\hline
\end{tabular}

Dari tabel diatas hasil analisis multivariat ada 1 (satu) variabel yaitu pengetahuan menghasilkan $\mathrm{p}>0.05$, berarti variabel tersebut dikeluarkan dari model. Hasil pemodelan dapat dilihat pada tabel berikut:
Tabel 5.

Analisis Multivariat (Pemodelan II) Tentang Kejadian Dermatitis Kontak Pada Petugas Pengangkut Sampah Di Tempat Pembuangan Akhir (TPA) Kota Tembilahan Tahun 2019

\begin{tabular}{lccc}
\hline \multicolumn{1}{c}{ Variabel } & $\begin{array}{c}\text { P } \\
\text { value }\end{array}$ & POR & B \\
\hline Personal higiene & 0.000 & 6.164 & 1.819 \\
Penggunaan APD & 0.025 & 1.460 & 0.378 \\
Lama Kontak & 0.000 & 3.148 & 1.147 \\
Umur & 0.000 & 3.362 & 1.213 \\
Jenis kelamin & 0.000 & 2.776 & 1.021 \\
Constanta & 0.000 & 0.000 & -9.109 \\
\hline
\end{tabular}

Analisis data multivariat pemodelan ke 2 (dua) seperti pada tabel di atas, didapatkan informasi bahwa dengan dikeluarkanya variabel pengetahuan ternyata tidak terjadi perubahan OR yang melebihi 10 persen seperti yang terlihat pada tabel 6. Karena itu variabel pengetahuan dikeluarkan dari model.

Tabel 6.

Perubahan Nilai Por Setelah Analisis Multivariat (Pemodelan II)

\begin{tabular}{lccc}
\hline $\begin{array}{c}\text { Variabel } \\
\text { Independen }\end{array}$ & $\begin{array}{c}\text { POR dengan } \\
\text { pengetahuan }\end{array}$ & $\begin{array}{c}\text { POR } \\
\text { Tanpa } \\
\text { pengetahuan }\end{array}$ & $\begin{array}{c}\text { Perubahan } \\
\text { POR } \\
\text { (Persen) }\end{array}$ \\
\hline Personal higiene & 5.998 & 6.164 & 2.7 \\
\hline Penggunaan APD & 1.476 & 1.460 & 1.08 \\
\hline Lama Kontak & 3.167 & 3.148 & 0.59 \\
\hline Umur & 3.377 & 3.362 & 0.44 \\
\hline Jenis kelamin & 2.719 & 2.776 & 2.09 \\
\hline
\end{tabular}

Setelah pengeluaran variabel pengetahuan maka terbentuk model seperti tabel berikut ini :

Tabel 7.

Analisis Multivariat (Pemodelan III) Tentang Kejadian Dermatitis Kontak Pada Petugas Pengangkut Sampah Di Tempat Pembuangan Akhir (TPA) Kota Tembilahan Tahun 2019

\begin{tabular}{lccc}
\hline Variabel & $\begin{array}{c}\text { P } \\
\text { value }\end{array}$ & POR & B \\
\hline Personal higiene & 0.000 & 6.164 & 1.819 \\
Penggunaan APD & 0.025 & 1.460 & 0.378 \\
Lama Kontak & 0.000 & 3.148 & 1.147 \\
Umur & 0.000 & 3.362 & 1.213 \\
Jenis kelamin & 0.000 & 2.776 & 1.021 \\
Constanta & 0.000 & 0.000 & - \\
& & & 9.109 \\
\hline
\end{tabular}

Selanjutnya dilakukan uji interaksi untuk membuktikan apakah variabel independen saling berinteraksi satu sama lainnya dalam 
mempengaruhi variabel dependen. Menurut Hastono (2007) apabila variabel tersebut berinteraksi maka akan membentuk suatu variabel baru dalam mempengaruhi variabel dependen. Hasil uji interaksi dapat dilihat pada tabel berikut:

Tabel 8.

Uji Interaksi Tentang Kejadian Dermatitis Kontak Pada Petugas Pengangkut Sampah Di Tempat Pembuangan Akhir (TPA) Kota Tembilahan Tahun 2019

\begin{tabular}{lc}
\hline \multicolumn{1}{c}{ Variabel } & $\begin{array}{c}\text { P } \\
\text { value }\end{array}$ \\
\hline Personal higiene vs penggunaan APD & 0.173 \\
Personal higiene vs lama kontak & 0.205 \\
Personal higiene vs umur & 0.155 \\
Personal higiene vs jenis kelamin & 0.408 \\
Penggunaan APD vs lama kontak & 0.694 \\
Penggunaan APD vs umur & 0.068 \\
Penggunaan APD vs jenis kelamin & 0.576 \\
Lama kontak vs umur & 0.332 \\
Lama kontak vs jenis kelamin & 0.993 \\
Umur vs jenis kelamin & 0.265 \\
\hline
\end{tabular}

Dari tabel di atas dapat diketahui bahwa tidak ada variabel hasil interaksi karena $\mathrm{p}$ value yang dihasilkan $>0.05$. Maka dengan demikian terbentuklah model akhir dalam pemodelan penelitian ini, dapat dilihat pada tabel berikut ini:

Tabel 9.

Analisis Multivariat (Pemodelan IV) Tentang

Kejadian Dermatitis Kontak Pada Petugas

Pengangkut Sampah Di Tempat Pembuangan

Akhir (TPA) Kota Tembilahan Tahun 2019

\begin{tabular}{lccc}
\hline \multicolumn{1}{c}{ Variabel } & $\begin{array}{c}\text { P } \\
\text { value }\end{array}$ & POR & B \\
\hline Personal higiene & 0.000 & 6.164 & 1.819 \\
Penggunaan APD & 0.025 & 1.460 & 0.378 \\
Lama Kontak & 0.000 & 3.148 & 1.147 \\
Umur & 0.000 & 3.362 & 1.213 \\
Jenis kelamin & 0.000 & 2.776 & 1.021 \\
Constanta & 0.000 & 0.000 & - \\
& & & 9.109 \\
\hline
\end{tabular}

Dari tabel diatas hasil analisis multivariat semua variabel menghasilkan $\mathrm{p}<0.05$, berarti semua variabel berhubungan bermakna dengan kejadian dermatitis kontak pada petugas pengangkut sampah di Tempat Pembuangan Akhir (TPA) Kota Tembilahan Tahun 2019, maka kesimpulan hasil penelitian sebagai berikut: a. Petugas pengangkut sampah dengan personal higiene tidak baik berisiko untuk mendapatkan kejadian dermatitis kontak 6.164 kali lebih tinggi dibandingkan dengan personal higiene cukup setelah dikontrol oleh variabel penggunaan APD, lama kontak, umur dan jenis kelamin.

b. Petugas pengangkut sampah dengan penggunaan APD tidak pernah berisiko untuk mendapatkan kejadian dermatitis kontak 1.460 kali lebih tinggi dibandingkan dengan penggunaan APD jarang atau selalu setelah dikontrol oleh variabel personal higiene, lama kontak, umur dan jenis kelamin.

c. Petugas pengangkut sampah dengan lama kontak berisiko mempunyai risiko untuk mendapatkan kejadian dermatitis kontak 3.148 kali lebih tinggi dibandingkan dengan lama kontak tidak risiko setelah dikontrol oleh variabel penggunaan APD, personal higiene, umur dan jenis kelamin.

d. Petugas pengangkut sampah dengan umur diatas 31 tahun mempunyai risiko untuk mendapatkan kejadian dermatitis kontak 3.362 kali lebih tinggi dibandingkan dengan umur dibawah atau sama dengan 31 tahun setelah dikontrol oleh variabel penggunaan APD, personal higiene , lama kontak dan jenis kelamin.

e. Petugas pengangkut sampah perempuan mempunyai risiko untuk mendapatkan kejadian dermatitis kontak 2.776 kali lebih tinggi dibandingkan dengan laki-laki setelah dikontrol oleh variabel penggunaan APD, personal higiene, lama kontak dan umur.

f. Urutan variabel yang paling besar pengaruhnya terhadap kejadian dermatitis kontak pada petugas pengangkut sampah di TPA Kota Tembilahan tahun 2018 adalah personal higiene (POR 6.614), umur 
(POR 3.362), lama kontak (POR 3.148) dan jenis kelamin (POR 2.776)

g. Tidak ada variabel yang confounding dan interaksi

Dari hasil analisis bivariat variabel independen yang berhubungan dengan kejadian dermatitis kontak adalah variabel: personal higiene, lama kontak, penggunaan APD, umur dan jenis kelamin. Hubungan sebab akibat antara variabel independen ditentukan antara lain : hubungan temporal, plausability, kekuatan asosiasi, konsistensi, dose respon relationship, jenis desain. Petugas pengangkut sampah dengan personal higiene tidak baik berpeluang untuk mengalami dermatitis kontak 4.94 kali lebih tinggi dibandingkan dengan personal higiene cukup (CI 95 persen:2.968.26). Menurut Wiknjosastro (2002). Personal hygiene dari bahasa Yunani yaitu personal yang artinya perorangan dan higiene berarti sehat. Kebersihan perorangan adalah cara perawatan diri manusia untuk memelihara kesehatan. Kebersihan perorangan sangat penting untuk diperhatikan. Pemeliharaan kebersihan perorangan diperlukan untuk kenyamanan individu, keamanan dan kesehatan. Hasil penelitian ini sama dengan penelitian yang dilakukan oleh Yeni (2013) menyatakan terdapat hubungan yang bermakna antara gangguan kulit dengan personal hygiene yang buruk pada pekerja, dimana pengukuran personal hygiene dilakukan dengan menggunakan kuesioner yang berisi 9 pertanyaan mengenai kerbersihan kulit responden sebelum dan sesudah bekerja dimana 9 pertanyaan tersebut berisi poin-poin penilain personal hygiene. Penilain personal hygiene dibedakan menjadi 2 yaitu personal hygiene dinilai baik jika poin $>25$ poin dan personal hygiene dinilai buruk jika poin $<24$ poin. Menurut peneliti personal hygiene berkaitan dengan diri individu termasuk perilaku dan kebiasaan sehari-hari. Untuk mencegah terjadinya penyakit dermatitis personal hygiene harus dijaga setiap hari. Hasil penelitian menemukan bahwa Ada hubungan antara penggunaan APD dengan kejadian dermatitis kontak (pvalue $=0.00$ ). Menurut Andani (2009) menyatakan bahwa APD merupakan seperangkat alat yang dipergunakan oleh tenaga kerja untuk melindungi sebagian/ seluruh tubuhnya terhadap kemungkinan adanya potensi bahaya/kecelakaan kerja. seperti untuk melindungi kepala dari benda keras, pukulan dan benturan, terjatuh dan terkena arus listrik, pelindung muka dan mata, pelindung telinga, pelindung pernafasan, pelindung tangan dan kaki, pakaian pelindung, dan safety belt. Bagi petugas pengumpul sampah APD sangat diperlukan untuk melindungi dirinya terhadap potensi bahaya. Kecelakaan kerja. Beberapa jenis APD standar yang perlu dilengkapi oleh petugas sampah adalah alat pelindung kepala, alat pelindung tangan, dan alat pelindung kaki.

Menurut Slamet J (2002) menyatakan bahwa pentingnya manfaat APD seperti helm selain berfungsi untuk melindungi kepala dari terik matahari juga untuk melindungi dari benturan benda keras atau terjatuh dari mobil, demikian juga sepatu boot untuk melindungi kaki dari bendabenda tajam seperti duri atau pecahan beling, sarung tangan untuk melindungi tangan dari benda tajam juga melindungi tangan agar terhindar dari pengotoran oleh sampah yang banyak mengandung mikroorganisme pathogen, masker yang berfungsi untuk melindungi hidung dari bau misalnya gas-gas dari hasil dekomposisi sampah organik yang bsia menyebabkan gangguan sakit kepala bahkan keracunan, yang menyebabkan kematian.

Hasil penelitian ini sesuai dengan yang dilakukan Ambarsari (2018) menemukan bahwa ada pengaruh yang signifika antara penggunaan APD dengan kejadian dermatitis kontak. Menurut peneliti budaya penggunaan APD pagi petugas pengumpul sampah masih kurang baik karena menurut mereka mengganggu kenyamanan mereka dalam beraktivitas. 
Menurut Suma'mur (2009) menyatakan bahwa dalam UU No. 13 tahun 2003 tentang Ketenagakerjaan menjelaskan tentang ketentuan pembagian jam kerja adalah 7-8 jam sehari dan 40 jam seminggu. Memperpanjang waktu kerja lebih dari kemampuan lama kerja biasanya tidak disertai efisiensi, efektivitas, dan produktivitas yang optimal bahkan biasanya terjadi penurunan kualitas dan hasil kerja serta bekerja dengan waktu yang berkepanjangan akan menimbulkan terjadinya kelelahan, gangguan kesehatan dan penyakit. Berdasarkan Undang-Undang RI No. 13 Tahun 2003 juga menjelaskan bahwa setiap pengusaha harus melaksanakan ketentuan jam kerja seperti yang diatur oleh undang-undang. Ada 2 sistem yang diatur dalam penentuan jam kerja, yaitu: 1) 7 jam kerja dalam 1 hari atau 40 jam kerja dalam 1 minggu untuk 6 hari kerja dalam 1 minggu, atau 2) 8 jam kerja dalam 1 hari atau 40 jam kerja dalam 1 minggu untuk 5 hari kerja dalam 1 minggu. Bekerja yang melebihi 8 jam sehari mengakibatkan penurunan dalam total prestasi dan penurunan kecepatan kerja yang disebabkan kelelahan. Bekerja selama 8 jam per hari dapat diambil sebagai suatau kondisi yang optimal. Meskipun demikian waktu istirahat harus tetap diadakan.

Berdasarkan penelitian yang dilakukan oleh Yeni (2013) didapatkan hasil kejadian gangguan kulit akibat kerja pada variabel lama kontak dengan rata-rata lama kontak 9 jam sehari, sebanyak 40 dari 66 pekerja mengalami gangguan kulit. Lama kontak merupakan jangka waktu pekerja berkontak dengan bahan kimia dan iritan dalam hitungan jam/hari.

Menurut peneliti lama kontak petugas pengumpul sampah di Kota Tembilahan rata-rata masih rendah, tetapi karena keterpaparan dengan sampah berbahaya bisa menyebabkan dermatitis kontak.

Hasil penelitian menemukan bahwa petugas pengangkut sampah dengan umur $<31$ tahun berpeluang untuk mengalami dermatitis kontak 41.78 kali lebih tinggi dibandingkan dengan umur $\geq 31$ tahun (CI
95\%:1.10-2.87). Menurut Iwan (2003) menyatakan bahwa umur merupakan salah satu faktor risiko yang dapat mempengaruhi kejadian gangguan kulit pada pekerja dimana sesorang dengan umur yang semakin tua akan berdampak pada sistem kekebalan tubuh manusia yang berkurang dan rentan terkena penyakit. Dapat dikatakan bahwa dermatitis atau gangguan kulit akan lebih mudah menyerang pada usia yang lebih tua. Sedangkan menurut Cohen (1999) menyatakan bahwa umur diukur sejak seseorang lahir hingga saat ini. Seiring bertambahnya usia kulit manusia mengalami degenerasi, seperti kulit kehilangan lapisan lemak diatasnya menjadi lebih kering (Cohen,1999).

Berdasarkan hasil penelitian yang dilakukan di tempat pengolahan sampah oleh Mausulli (2010) hasil analisa hubungan antara usia dengan dermatitis kontak sebanyak 52,6 persen pekerja usia $\leq$ 31 tahun terkena dermatitis kontak, sedangkan pekerja usia $>31$ tahun terkena dermatitis kontak sebanyak 56,8 persen.

Berdasarkan penelitian yang dilakukan oleh Nurtanti (2010) kejadian gannguan kulit pada pekerja perempuan lebih bermakna bila dibandingkan dengan pekerja laki-laki. Menurut peneliti jenis kelamin pekerja pengangkut sampah sangat berkaitan dengan ketahanan dan daya tahan tubuh untuk mendapatkan penyakit akibat kontak dengan kuman atau bibit penyakit dimana perempuan lebih rentan daripada laki laki.

Hasil penelitian menemukan bahwa petugas pengangkut sampah dengan pengetahuan buruk berpeluang untuk mengalami dermatitis kontak 1.88 kali lebih tinggi dibandingkan dengan pengetahuan baik (CI 95 persen:1.07-3.31). Menurut Notoatmodjo (2005) pengetahuan adalah hasil tahu, dan terjadi pada seseorang melakukan penginderaan terhadap objek tertentu. Pendidikan yang rendah mengakibatkan rendahnya kepedulian terhadap pencegahan penyakit. Pendidikan dapat membawa wawasan atau pengetahuan seseorang. Kurangnya pengetahuan pekerja mengenai dermatitis 
kontak menyebabkan pekerja tidak melakukan pekerjaan secara aman untuk mencegah terjadinya dermatitis.

Menurut Mubarak (2007) menyatakan bahwa faktor yang dapat memengaruhi pengetahuan seseorang atau kelompok adalah edukasi. Edukasi adalah suatu petunjuk yang diberikan seseorang terhadap orang lain mengenai suatu hal yang dapat dimengerti. Pada umumnya, seseorang dengan tingkat edukasi yang lebih tinggi akan lebih mudah untuk menerima informasi yang akhirnya akan lebih banyak pengetahuan yang didapat. Di sisi lain, jika tingkat edukasi seseorang rendah, akan menghambat perkembangan perilaku seseorang untuk menerima informasi dan nilai baru yang didapat.

Berdasarkan penelitian yang dilakukan oleh Aisyah (2010) angka kejadian gangguan kulit pada pemulung yang tidak bersekolah lebih bermakna bila dibandingkan dengan pemulung yang bersekolah.

Menurut peneliti pada umumnya rendahnya pengetahuan petugas pengumpul sampah terhadap penyakit dermatitis kontak karena informasi yang mereka peroleh sangat minim.

Dari analisa multivariat menggunakan uji regresi logistik dengan menggunakan model prediksi yang bertujuan mengestimasi secara valid hubungan variabel personal higiene, penggunaan APD, lama kontak, umur, jenis kelamin dan pengetahuan dengan kejadian dermatitis kontak. Setelah dilakukan uji regresi logistik secara bertahap dimulai dari $\mathrm{p}>$ 0,05 tertinggi dikeluarkan dari model. Dari tabel diatas hasil analisis multivariat semua variabel menghasilkan $p<0.05$, berarti 5 (lima) variabel berhubungan bermakna dengan kejadian dermatitis kontak yaitu :

1. Petugas pengangkut sampah dengan personal higiene tidak baik berisiko untuk mendapatkan kejadian dermatitis kontak 6.164 kali lebih tinggi dibandingkan dengan personal higiene cukup setelah dikontrol oleh variabel penggunaan APD, lama kontak, umur dan jenis kelamin.

2. Petugas pengangkut sampah dengan umur diatas 31 tahun mempunyai risiko untuk mendapatkan kejadian dermatitis kontak 3.362 kali lebih tinggi dibandingkan dengan umur dibawah atau sama dengan 31 tahun setelah dikontrol oleh variabel penggunaan APD, personal higiene , lama kontak dan jenis kelamin.

3. Petugas pengangkut sampah dengan lama kontak berisiko mempunyai risiko untuk mendapatkan kejadian dermatitis kontak 3.148 kali lebih tinggi dibandingkan dengan lama kontak tidak risiko setelah dikontrol oleh variabel penggunaan APD, personal higiene, umur dan jenis kelamin.

4. Petugas pengangkut sampah perempuan mempunyai risiko untuk mendapatkan kejadian dermatitis kontak 2.776 kali lebih tinggi dibandingkan dengan lakilaki setelah dikontrol oleh variabel penggunaan APD, personal higiene, lama kontak dan umur.

5. Petugas pengangkut sampah dengan penggunaan APD tidak pernah berisiko untuk mendapatkan kejadian dermatitis kontak 1.460 kali lebih tinggi dibandingkan dengan penggunaan APD jarang atau selalu setelah dikontrol oleh variabel personal higiene, lama kontak, umur dan jenis kelamin.

\section{KESIMPULAN}

Berdasarkan uraian pada hasil dan pembahasan, maka dengan ini penelitian mengambil kesimpulan sebagai berikut :

1. Petugas pengangkut sampah dengan personal higiene tidak baik berpeluang untuk mengalami dermatitis kontak 4.94 kali lebih tinggi dibandingkan dengan personal higiene cukup (CI 95 persen:2.96-8.26).

2. Ada hubungan antara penggunaan APD dengan kejadian dermatitis kontak (pvalue $=0.00$ )

3. Petugas pengangkut sampah dengan lama kontak $>8$ jam berpeluang untuk 
4. mengalami dermatitis kontak 3.86 kali lebih tinggi dibandingkan dengan lama kontak $\leq 8$ jam $\quad$ (CI 95 persen:2.21$6.75)$.

5. Petugas pengangkut sampah dengan umur < 31 tahun berpeluang untuk mengalami dermatitis kontak 41.78 kali lebih tinggi dibandingkan dengan umur $\geq 31$ tahun (CI 95 persen:1.10-2.87).

6. Petugas pengangkut sampah perempuan berpeluang untuk mengalami dermatitis kontak 2.78 kali lebih tinggi dibandingkan dengan laki-laki (CI 95 persen:1.72-4.78).

7. Tidak ada pengaruh pengetahuan dengan kejadian dermatitis pada petugas pengangkut sampah di Kota Tembilahan

\section{DAFTAR PUSTAKA}

Abul, S.(2010.) Environmental And Health Impact Of Solid Waste Disposal. Journal. University of Swaziland. Diakses Pada Tanggal 13 Mei 2016.

Alqahtani dan Otaibi . 2015. Management of Contact Dermatitis. file:///F:/baruuuu/Management\%20of $\% 20$ contact\%20dermatitis.htm.

Journal of Dermatology \& Dermatologic Surgery. Diakses pada Tanggal 12 Maret 2016.

Budiman, C. (2007.) Pengantar Kesehatan Lingkungan. Kedokteran EGC. Cetakan Pertama. Jakarta.

Budiono dan Cahyawati. (2011). Faktor Yang Mempengaruhi Kejadian Dermatitis Pada Nelayan. Jurnal Kesehatan Masyarakat.

Cahyono, B. (2004) Keselamatan Kerja Bahaya Kimia Industri. Gadja Mada University Press. Yogyakarta.

Dalimunthe, Khadijah. (2016). Pengaruh Karakteristik, Personal Hygiene, dan Alat Pelindung Diri (Apd) Dengan
Gangguan Kelainan Kulit Pada Petugas Pengangkut Sampah Di Kota Padangsidimpuan Tahun 2016. Volume 1, Nomor 1, Mei 2017. Diakses pada tanggal 7 September 2018.

Dingwall, L. (2010). Higiene Personal. Kedokteran EGC. Jakarta. Erliana. 2008. Hubungan Karakteristik Individu dan Penggunaan Alat Pelindung Diri dengan Kejadian Dermatitis Kontak Pada Pekerja Paving Block CV. Lhoksumawe. Universitas Sumatera Utara.

Fajar, I. (2009). Statistik untuk Praktisi Kesehatan. Graha Ilmu. Cetakan Pertama. Yogyakarta.

Faridawati. (2013). Hubungan Antara Personal Higiene Dan Karakteristik Individu Dengan Keluhan Gangguan Kulit Pada Pemulung (Laskar Mandiri) di Kelurahan Sumur Batu Kecamatan Bantar Gebang. Universitas Islam Negeri Sarif Hidayatullah. Skripsi kesehatan Lingkungan. Jakarta.

Harahap, M. (2000). Ilmu Penyakit Kulit. Hipokrates. Jakarta. Hayat. 2012. Skala Pengukuran. http://hayat08.files.wordpress.com/2 012/03/stat-1.pdf. Diakses pada Tanggal 12 Maret 2016.

HSE.( 2000). The Prevalence Of Occupational Dermatitis Amongst Printers In The Midlands. Her Majesties Stationery Office. Diakses tanggal 2 Maret 2016.

Isro'n, L. dan Andarmoyo, S. (2012). Personal Higiene, Konsep, Proses dan Aplikasi. Praktik Keperawatan. Cetakan Pertama. Graha Ilmu. Yogyakarta. 
Kementerian Kesehatan Republik Indonesia. 2012. Profil Kesehatan Indonesia Tahun 2011. Ditjen Bina Upaya Kesehatan. Jakarta.

Lawita, dkk. (2015). Hubungan Faktor Lingkungan Dengan Kejadian Dermatitis Pada Anak Usia Sekolah Di Desa Tabang Barat Kecamatan Rainis Kabupaten Kepulauan Talaud. E-journal Keperawatan (e-Kp) Volume 3 Nomor 2, Oktober 2015. Program Studi Ilmu Keperawatan Fakultas Kedokteran Universitas Sam Ratulangi. Diakses pada tanggal 7 September 2018

Listautin. (2012). Pengaruh Lingkungan Tempat Pembuangan Akhir Sampah, Personal Higiene, Indeks Massa Tubuh (IMT) Terhadap Keluhan Kesehatan Pada Pemulung di Kelurahan Terjun Medan Marelan Tahun 2012. Fakultas Kesehatan Masyarakat. Universitas Sumatera Utara.

Mahyuni, (2012). Dermatosis (Kelainan Kulit) Ditinjau Dari Aspek Keselamatan dan Kesehatan Kerja Pada Pemulung Di Tpa Terjun Medan Marelan. Jurnal. Universitas Diponegoro. Semarang.

Pratama, Karunia Friska dan Corie. (2016). Gangguan Kulit Pemulung Di Tpa Kenep Ditinjau Dari Aspek Keselamatan Dan Kesehatan Kerja. (C)2017 FKM_UNAIR All right reserved. Open access under CC BY - SA license doi: 10.20473/ijosh.v6i2.2017.135-145.

Received 30 Desember 2016, received in revised form 2 February 2017, Accepted 5 April 2017, Published online: 30 August 2017.

Sagita, M. (2015). Determinan Kejadian Gangguan Kulit Pada Pemulung Di Tpa Sukawinatan Palembang.
Skripsi. Universitas Sriwijaya. Diakses Pada Tanggal 13 Mei 2016.

Nicholson. (2002). Occupational Health in The European Union. Society of occupational Medicine. Great Britain.

Palupi, W. dan Monica, E. (2006). Bahaya Bahan Kimia Pada Kesehatan Manusia dan Lingkungan. Cetakan Pertama. Kedokteran EGC. Jakarta.

Potter. (2005). Fundamental keperawatan. Cetakan Keempat. Kedokteran EGC. Jakarta.

Safriyanti. (2016). Hubungan Personal Hygiene, Lama Kontak Dan Riwayat Penyakit Kulit Dengan Kejadian Dermatitis Kontak Pada Petani Rumput Laut Di Desa Akuni Kecamatan Tinanggea Kabupaten Konawe Selatan Tahun 2016. Fakultas Kesehatan Masyarakat Universitas Halu Oleo. Diakses pada tanggal 7 September 2018.

Satusi, H. R. (2003). Proporsi Dermatosis Serta Gambaran Faktor-Faktor Yang Berkaitan Pada Pekerja Industri Batik Kota Sukarta. Universitas Diponegoro. Semarang.

Saryono dan Widianti, T. (2011). Catatan Kuliah Kebutuhan Dasar Manusia (KDM). Cetakan Kedua. Nuha Medika. Yogyakarta.

Suwondo, Jayanti, dan Lestantyo. (2010). Faktor-faktor yang berhubungan Dengan Kejadian Dermatitis Kontak Pekerja Industri Tekstil di Jepara. Jurnal. Universitas Diponegoro.

Suryani, Febria. (2011). Faktor-Faktor yang Berhubungan dengan Dermatitis Kontak Pada Pekerja Bagian Proccesing dan Filling PT. Cosmar 
Health Care : Jurnal Kesehatan 10 (1) Juni 2021 (150-161)

I ndonesia Tangerang Selatan Tahun 2011. Universitas Islam Negeri, Jakarta. Diakses Pada Tanggal 13 Mei 2016.

Susanty, E. (2015). Hubungan Personal Hygiene Dan Karakteristik Individu Terhadap Kejadian Dermatitis Pada Petani Rumput Laut Di Dusun Puntondo Kabupaten Takalar.Skripsi. Universitas Hasanuddin. Diakses Pada Tanggal 13 Mei 2016. 